\title{
Micralestes eburneensis Daget 1965 (Characiformes: Alestidae), a Near Threatened Fishes of the World
}

Richard Jean Olive Doffou, Felix Koffi Konan (Corresponding Author), Gustave N'Guessan Aliko, Charles Koffi Boussou, Yves Kotchi Bony

Department of Environment, University Jean Lorougnon Guédé

BP 150 Daloa, Ivory Coast

E-mail: konanfelix@yahoo.fr

Germain Gourene

Laboratory of Aquatic Environment and Biology

Department of Sciences and Environment Management, University Nangui Abrogoua

02 BP 801 Abidjan 02, Ivory Coast

Received: August 1, 2018 Accepted: August 23, 2018 Published: November 21, 2018

doi:10.5296/ast.v7i1.13943 URL: https://doi.org/10.5296/ast.v7i1.13943

\begin{abstract}
Micralestes eburneensis Daget 1965, an endemic characin fish of Ivory Coast / Liberia is assessed as Near Threatened due to its restricted range. In addition, there is strong fishing pressure, habitat loss and aquatic pollution from clandestine gold mining in the Cavally River bed.

Moreover, given the development and intensification of mining activities in the study area, it is to be expected that the population of the endemic species will continue to decline. The strong anthropogenic pressure in this region on the Cavally hydrosystem and its environment must be taken into account for a future update of M. eburneensis conservation status.

There is an immediate need for developing protection and management actions for this fish species.
\end{abstract}

Keywords: Micralestes eburneensis, Alestidae, Near Threatened Fish, West Africa.

\section{Synonyms}

Hemigrammopetersius (Rhabdalestes) eburneensis Géry, 1977, Rhabdalestes eburneensis Poll, 1967 (IUCN, 2017a; Eschemeyer et al., 2017). 


\section{I Macrothink}

\section{Common Names}

Freshwater characin fish (in English). "Vhe " (in Yacouba, ethnic group in western Ivory Coast) (Figure 1).
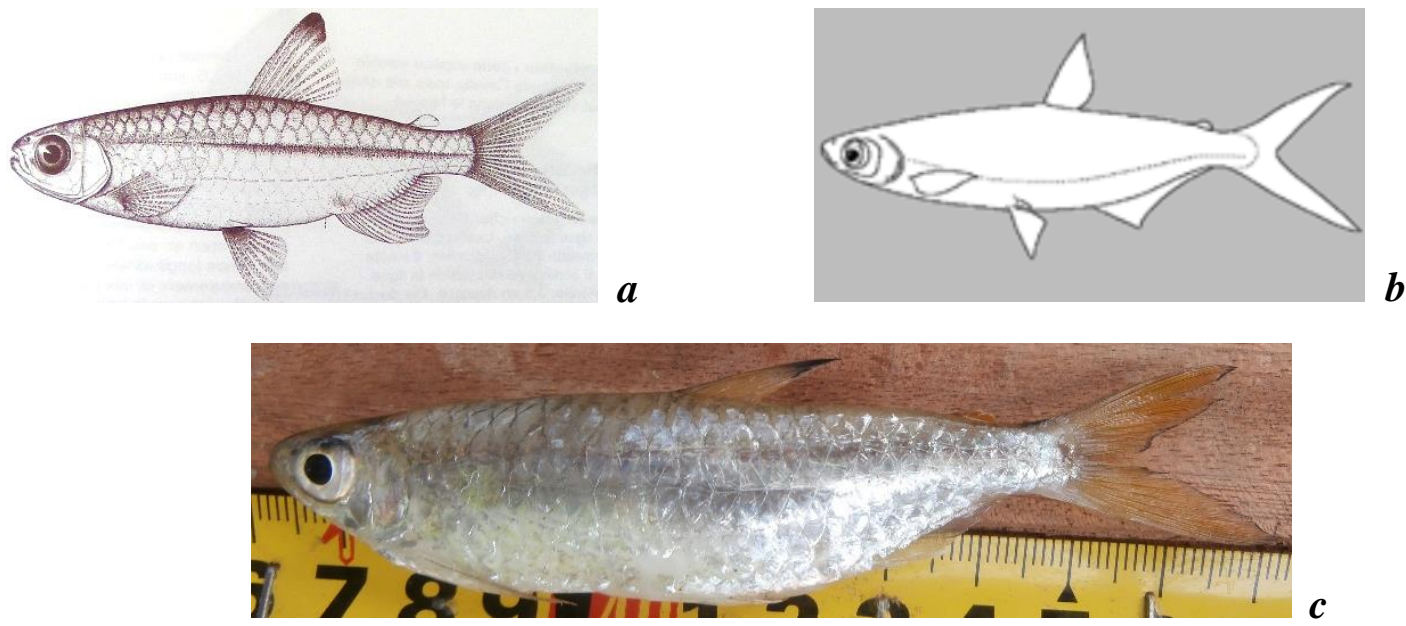

Figure 1. Micralestes eburneensis: a) picture from Lévêque et al. (1990); b) picture from Froese and Pauly (2017); c) sample from the Cavally River. Photo Courtesy: Felix Koffi

KONAN

\section{Taxonomic Notes}

Described as Rhabdalestes eburneensis (Daget 1965) or Hemigrammopetersius (Rhabdalestes) eburneensis Géry, 1977 from the Cavaly River in Western Africa (Paugy, 1984). The current status or valid name is Micralestes eburneensis Daget 1965 (Lévêque et al., 1990 ; Paugy, 1990 ; IUCN, 2017a; Pezold et al., 2016 ; Eschemeyer et al., 2017).

\section{Geographic Range Information}

The Cavally River watershed is shared between three West African countries: Guinea, Côte d'Ivoire and Liberia. Located between $6^{\circ} 47^{\prime}$ and $6^{\circ} 52^{\prime}$ north latitude, and between $8^{\circ} 5^{\prime}$ and $8^{\circ} 6^{\prime}$ west longitude, it has a length of $700 \mathrm{~km}$ and covers a catchment area of $28800 \mathrm{~km}^{2}$ (Koffi, 2017).

Micralestes eburneensis has a very limited distribution in the west of Ivory Coast (in the Cavally and Nipoué (Cess) Rivers) (Teugels et al., 1988; Paugy, 1990; 2003). An overview of the Cavally River basin and the study area are shown in Figure 2. On the Cavally River, the areas in which this species was regularly observed during this study are shown in Table 1. 


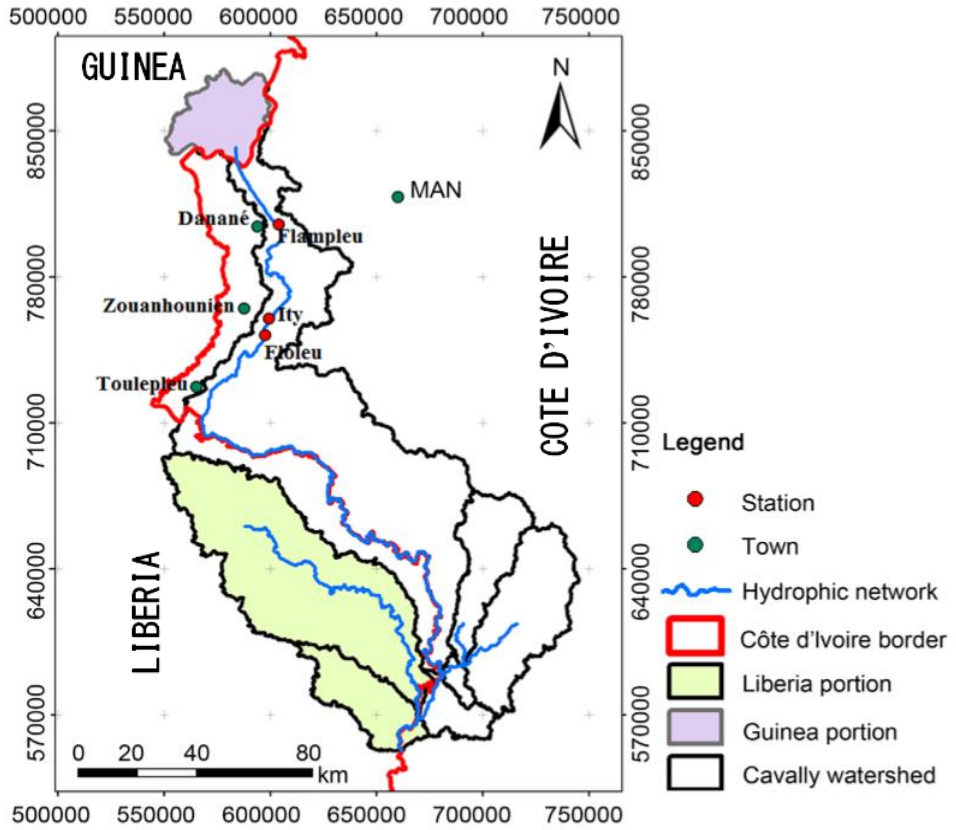

Figure 2. Overview of the Cavally sub-watershed studied (source: Brou et al. (2017) (modified))

Table 1. Location of sampling sites on the Cavally River during this study in Western of Ivory Coast

\begin{tabular}{l|l|l}
\hline Sampling sites & \multicolumn{2}{|l}{ Geographic coordinates (UTM) } \\
\hline L1 Flampleu Cavally & N 0603178 & W 0802055 \\
L2 Zanhounien & N 0598469 & W 0786150 \\
L3 Liepleu & N 0598613 & W 0784563 \\
D1 Walter & N 0599444 & W 0760655 \\
D2 Dohoudopleu & N 0599422 & W 0760001 \\
D3 Teadia & N 0599591 & W 0759146 \\
D4 Dahapleu & N 0599019 & W 0784094 \\
F1 Tampieu & N 0598924 & W 0757144 \\
F2 Floleu-Kampiepleu & N 0598226 & W 0757243 \\
F3 Gnouleu & N 0598120 & W 0755721 \\
F4 Floleu-Sokloaleu & N 0597611 & W 0752074 \\
F5 Gueiosepleu (Bin-Houyé) & N 0587006 & W 0742170 \\
F6 Glareu (Bin-Houyé) & N 0583094 & W 0738210 \\
\hline
\end{tabular}




\section{Fishery and Populations}

Micralestes eburneensis is regularly present in artisanal fisheries in the Cavally River in Danané, Zouan-Hounien and Bin-Houyé in the western Ivory Coast (Doffou, 2014; Konan, 2015; Konan et al., 2015; Kouassi et al., 2017). This species is one of the small pelagic fish species regularly caught using gill net and fish traps widely used in artisanal fisheries.

During the study period, the species Micralestes eburneensis is the most abundantly fished (22.56\% of the total abundance observed) in this study (Konan, 2015; Konan et al., 2015). It has been observed at all sampling stations and at all seasons.

In this study, the standard length and the total weight of the specimens observed vary from 45 $\mathrm{mm}$ to $92 \mathrm{~mm}$ and from $3 \mathrm{~g}$ to $10 \mathrm{~g}$ respectively. The standard length reported by Ibala-Zamba and Vreven (2008) is $89 \mathrm{~mm}$.

\section{Habitat and Ecology}

M. eburneensis is a tropical freshwater pelagic fish species (Froese and Pauly, 2017). Table 2 presents some characteristics of the Cavally River where the species was observed during this study. The stream is bordered by a gallery forest with a large flood zone. The substrate is characterized by clay / silt, by a mixture of plant silt / debris with presence of rock block at certain sites.

Table 2. Some characteristics of the living environment of Micralestes eburneensis in Cavally Rivers in Western of Ivory Coast.

\begin{tabular}{lll}
\hline Parameters & Minimum & Maximum \\
\hline Transparency $(\mathrm{cm})$ & 42 & 94.30 \\
Temperature $\left({ }^{\circ} \mathrm{C}\right)$ & 24.60 & 28.30 \\
Conductivity $(\mu \mathrm{S} / \mathrm{cm})$ & 30 & 190 \\
Redox potential $(\mathrm{mV})$ & 50.80 & 98.58 \\
$\mathrm{pH}$ & 6.22 & 8.44 \\
Dissolved solids $(\mathrm{ppm})$ & 14 & 85 \\
Canopy $(\%)$ & 20 & 70 \\
\hline
\end{tabular}

\section{Biology}

Age and size at first sexual maturity of Micralestes eburneensis is 0.6 years and $63 \mathrm{~mm}$ in total length (TL) respectively (Froese and Pauly, 2017). The parameters of the allometric length-weight relationship estimated by Froese et al. (2013) are the following: $a=0.01148$ $(0.00519-0.02541)$ and $b=3.00(2.81-3.19)$. Other life history and population characters of M. eburneensis include Trophic level $=3.1$; Life span $=2$ years; Length to infinity $=95 \mathrm{~mm}$; Minimum population doubling time $\leq 15$ months (Froese and Pauly 2017). The intrinsic vulnerability to fishing of M. eburneensis is estimated at $10 \%$ (low vulnerability) (Cheung et al., 2005). M. eburneensis is considered to be an omnivorous feeder (Froese and Pauly 2017). Concerning reproductive biology, nothing much information is available in the literature (Froese and Pauly, 2017). 


\section{MInstitute ${ }^{\text {Mink }}$}

\section{Threats}

Sections of the Cavally river suffers from strong anthropogenic pressure mostly related to gold mining. This intensive gold mining activity by using motorized equipment in the river bed has led to water pollution, destabilization of riverbanks, destruction of the forest gallery, disruption of ecosystem functioning, modification of the substrate, high noise levels and high concentration of suspended solids. Konan et al. (2015) and Kouassi et al. (2017) point out that the habitats located in the Zouan-hounien area are particularly threatened by these anarchic gold panning activities. The strong anthropogenic pressure in this sector of the river causes the loss of habitats, in particular for Micralestes eburneensis which is endemic to this hydrosystem (Figure 3). Overharvest is also a major threat to the species given its importance as a food fish (Konan, 2015; Konan et al., 2015).

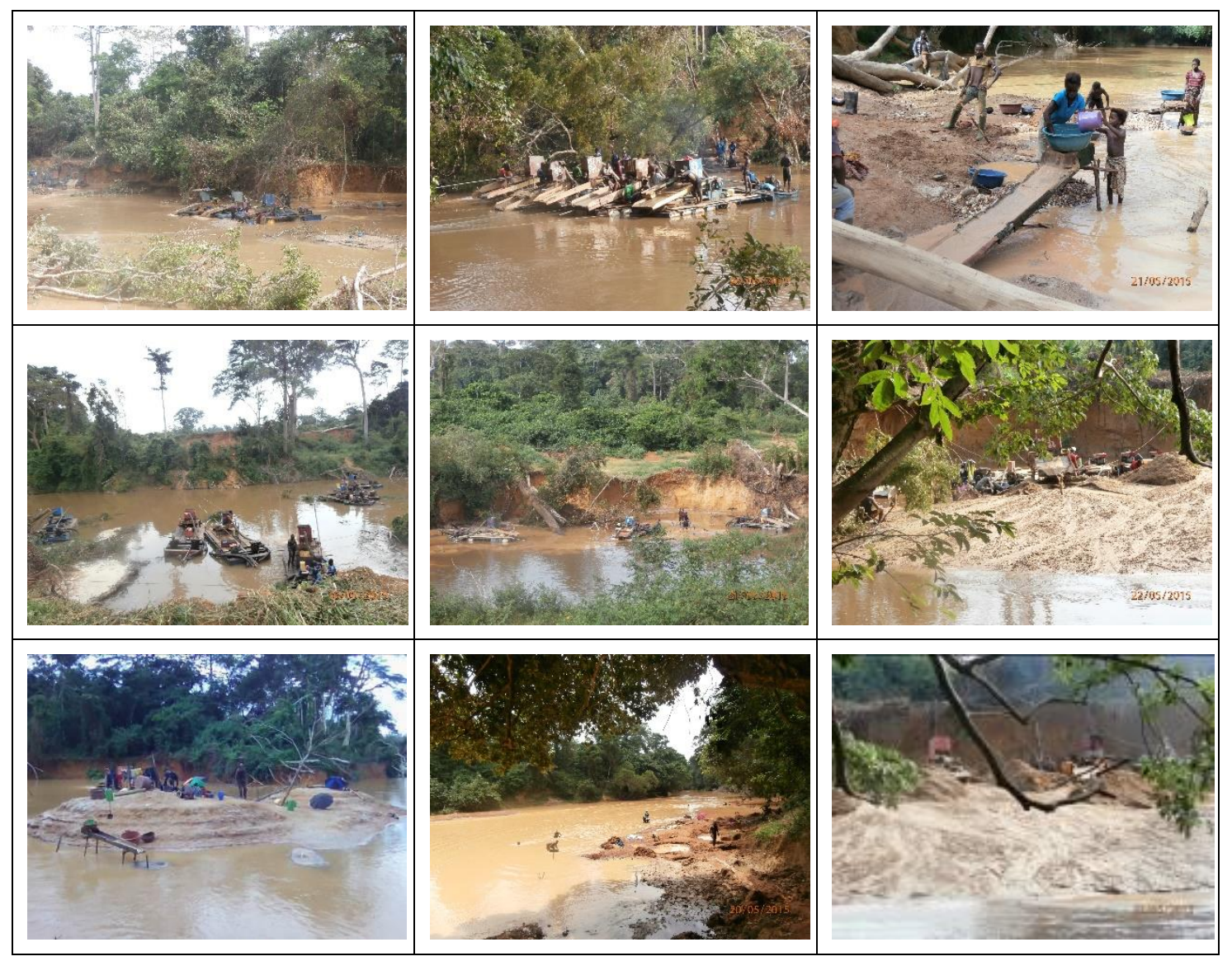

Figure 3. Overview of illegal gold mining activities on the Cavally River and their impacts on the watercourse. Photo Courtesy: Felix Koffi KONAN

\section{Use and Trade}

M. eburneensis has no direct economic value. However, caught by artisanal fishers in the Danané region of Ivory Coast (Doffou, 2014; Konan, 2015; Konan et al., 2015; Kouassi et al., 2017), M. eburneensis is consumed and much appreciated by the local population, especially women and children. As such, it is an important source of animal protein and micronutrients in the diet of riparian rural populations. 
This small pelagic is also used as bait by local fishermen to catch larger and more economically interesting species.

\section{Conservation Actions}

Concerning the hydrosystem Cavally:

- avoid any form of water and habitats pollution as currently observed in the Ity region;

- limit the regulation of the watercourse as currently planned to cut meanders from the riverbed in the region;

- prohibit the extraction of ores in the stream bed as currently observed in the study area;

- regulate mining activities in this region to respect the Performance Standard 6 (IFC, 2012) concerning the conservation of biodiversity and sustainable management of natural living resources.

Concerning the species, it is necessary to work to improve the knowledge on its biology, ecology and history of life. In this context, study has been initiated on aspects of biometrics, length-weight relationship, condition factor, population dynamics, reproduction and feeding ecology of M. eburneensis (Doffou, 2014; Konan, 2015; Konan et al., 2015). A broader study across Cavally River watershed needs to be conducted to better understand the species' distribution, stock assessment and map habitat loss areas for better conservation actions.

\section{Rational for the Red List Assessment}

Micralestes eburneensis is assessed as Near Threatened mainly based on its restricted distribution area (IUCN, 2017a). Indeed, this species is endemic to the Cavally River basin. On the whole portion of the river concerned by this study, the main threat to the survival of this species, is related to gold panning activities. As Doffou (2014), Konan (2015), Konan et al. (2015) and Kouassi et al. (2017) have also observed during their study, the catches of $M$. eburneensis have fallen sharply. But due to lack of specific research, there is no quantitative data available on its population dynamic. Given the development and intensification of mining activities in the study area, it is to be expected that the population of this endemic species will continue to decline. Moreover, there are few actions or policies for the conservation and protection of the Cavally hydrosystem on the one hand, and the inefficiency of gold mining regulatory policies in the study area on the other hand, this species would faces serious risk of extinction.

Concerning Area of Occupancy (AOO) and Extent of Occurrence (EOO), this endemic species is exposed to continuing degradation in habitat quality in relation with the growing gold mining activities and meets the IUCN criteria $B 1 a b(i$, ii, iii) and B2ab(iii) (IUCN, 2017b). In addition, current observations indicate a significant decline in the abundance of the species. Indeed, dominating the fish population in the study area (Doffou, 2014; Konan, 2015; Konan et al., 2015; Kouassi et al., 2017), the abundance of M. eburneensis dropped considerably during this study and meets the IUCN criteria Alac (IUCN, 2017b). This will 
need to be taken into account for a future revision / update of M. eburneensis conservation status in line with IUCN Red List criteria (IUCN, 2017a).

\section{References}

Brou, L. A., Kouassi, K. L., Konan, K. S., Kouadio, Z. A., Konan, K. F., \& Kamagaté, B. (2017). Rain-flow modeling using a multi-layer artificial neural network on the watershed of the Cavally River (Côte d'Ivoire). Journal of Water Resource and Protection, 9(12), 1403-1413. https://doi.org/10.4236/jwarp.2017.912090.

CITES, (2017). The Checklist of CITES species website. Appendices I, II and III valid from 04 April 2017. CITES Secretariat, Geneva, Switzerland. Compiled by UNEP-WCMC, Cambridge, UK. [Accessed 01/08/2017] https://www.cites.org/eng/app/appendices.php

Doffou, R. J. O. (2014). Biodiversité de la faune ichtyologique du fleuve Cavally à Ity (Côte d'Ivoire). Master's thesis of biodiversity and ecosystem valuation (Specialty: Hydrobiobiology), 54/2014: University Felix Houphouet Boigny (Ivory Cosat). 51.

Eschmeyer, W. N., Fricke, R., \& van der Laan, R. (Eds). (2017). Catalog of fishes: genera, species, references. (Electronic version accessed on 09 March 2018) (http://researcharchive.calacademy.org/research/ichthyology/catalog/fishcatmain.asp).

Froese, R., \& Pauly, D. (Eds). (2017). FishBase. World Wide Web electronic publication. www.fishbase.org, version (10/2017) (accessed on 09 March 2018).

Froese, R., Thorson, J., \& Reyes, Jr. R. B. (2013). A Bayesian approach for estimating length-weight relationships in fishes. Journal of Applied Ichthyology, 29, 1-7. https://doi.org/10.1111/jai.12299

Holland, R. A., Darwall, W. R. T., \& Smith, K. G. (2012). Conservation priorities for freshwater biodiversity: the Key Biodiversity Area approach refined and tested for $\begin{array}{lllll}\text { continental Africa. } & \text { Biological } & \text { Conservation, } & 148, & \end{array}$ https://doi.org/10.1016/j.biocon.2012.01.016

Ibala-Zamba, A., \& Vreven, E. (2008). Rhabdalestes yokai (Characiformes: Alestidae), a new species from the Léfini and Sangha River basins (Congo River basin), Africa. Ichthyological Exploration of Freshwaters, 19(4), 377-384.

IFC (2012). Guidance Note 6 Biodiversity Conservation and Sustainable Management of Living Natural Resources. Performance Standards and Guidance Notes - 2012 Edition. Internationale Finance Corporation. 69pp

IUCN (2017a). IUCN Red List of Threatened Species (Version 2017-1). IUCN 2017. IUCN Red List of Threatened Species. Downloaded in May 2017. http://www.iucnredlist.org/details/181754/0

IUCN (2017b). 2001 Categories \& Criteria (version 3.1). IUCN 2017. IUCN Red List of Threatened Species. Downloaded in 2017. http://www.iucnredlist.org/static/categories_criteria_3_1 
Koffi, B. (2017). Dimensionnement du canal de dérivation du fleuve Cavally à l'aide d'un modèle hydraulique 1D. Master's thesis in Water and Environmental Engineering: University Jean Lorougnon Guédé (Ivory Cosat). 50.

Konan, K. F. (2015). Inventaire ciblé des espèces de poissons d'intérêt pour la conservation Fleuve Cavally dans la zone d'influence des activités d'extension de la Société des Mines d'Ity (SMI) (Côte d'Ivoire). Study Report - Société des Mines d'Ity (SMI), Environment Division - SNC-Lavalin INC, University Jean Lorougnon Guédé. 34.

Konan, K. F., Niamen-Ebrottié, J. E., Bony, K. Y., \& Assemian, N. E. (2015). Etude hydrobiologique du fleuve Cavally / Etude d'Impact Environnemental et Social du Projet d'extension des activités de la Société des Mines d'Ity (SMI) (Côte d'Ivoire). Study Report Société des Mines d'Ity (SMI), 2D-Consulting Afrique, Environment Division - SNC-Lavalin INC, University Jean Lorougnon Guédé. 74.

Kouassi, K. L., Konan, K. F., \& Konan, K. S. (2017). Etat des lieux du fleuve Cavally dans le département de Zouan-Hounien (Ouest Côte d'Ivoire): Aperçu de la géomorphologie, l'hydrologie, l'hydrochimie et l'hydrobiologie. Rapport d'étude - Endeavour Mining-SMI, 63.

Paugy, D. (1984). Characidae. pp. 140-183. In: Daget J., Gosse J.-P., Thys van den Audenaerde D.F.E. (eds), Check-list of the freshwater fishes of Africa (CLOFFA). ORSTOM and MRAC, Paris and Tervuren. 1 .

Paugy, D. (1990). Characidae. pp. 195-236. In: Lévêque, C., Paugy, D., Teugels, G.G. (eds), Faune des poissons d'eaux douces et saumâtres de l'Afrique de l'Ouest. Tome I. Coll. Faune Tropicale $\mathrm{n}^{\circ}$ XXVIII. Musée Royal de l'Afrique Centrale, Tervuren et ORSTOM, Paris. 384.

Paugy, D. (2003). Alestidae. pp. 236-282. In: Paugy, D., Lévêque, C., Teugels, G.G. (eds), The fresh and brackish water fishes of West Africa Volume 1. Coll. faune et flore tropicales 40. Institut de recherche de développement, Paris, France, Muséum national d'histoire naturelle, Paris, France and Musée royal de l'Afrique Central, Tervuren, Belgium, 457.

Pezold, F., Schmidt, R. C., \& Stiassny, M. L. J. (2016). A survey of fishes of the Geebo Dugbe River confluence, Sinoe County, Liberia, with an emphasis on tributary creeks. Aqua International Journal of Ichthyology, 22(3), 97-122.

Teugels, G. G., Lévêque, C., \& Paugy, D., Traoré, K. (1988). Etat des connaissances sur la faune ichtyologique des bassins côtiers de Côte d'Ivoire et de l'ouest du Ghana. Revue d'Hydrobiologie Tropicale, 21(3), 221-237.

\section{Copyrights}

Copyright for this article is retained by the author(s), with first publication rights granted to the journal.

This is an open-access article distributed under the terms and conditions of the Creative Commons Attribution license (http://creativecommons.org/licenses/by/4.0/) 